\title{
DESIGN OF A MICROSTRIP ANTENNA ON DUROID 5870 SUBSTRATE MATERIAL FOR KU AND K-BAND APPLICATIONS
}

\author{
Mohammad Moinul Islam, Mohammad Tariqul Islam, Mohammad Rashed Iqbal Faruque
}

Original scientific paper

A microstrip antenna on Duroid 5870 substrate material has been presented for Ku and K-band applications in this paper. The proposed antenna has consisted of circular and rectangular slots printed on Duroid 5870 dielectric substrate material and excited by a $50 \Omega$ microstrip transmission line. High frequency electromagnetic solver HFSS has been taken into account in this study based on the Finite Element Method (FEM). The antenna has generated two separate resonant frequencies to cover Ku and K-band. It has an impedance bandwidth $(2: 1 \mathrm{VSWR})$ of $1,11 \mathrm{GHz}(16,14 \div 15,03 \mathrm{GHz})$ on the lower band and a bandwidth of $1,15 \mathrm{GHz}(20,99 \div 19,84 \mathrm{GHz})$ on the upper band. It has achieved a stable omni-directional radiation pattern in the operating frequency band. The efficiency, current distribution, VSWR, return loss of the proposed antenna have been presented and discussed in detail.

Keywords: Duroid 5870; K-band; Ku-band; microstrip antenna; microstrip line

Dizajn mikrostrip antene na materijalu podloge Duroid 5870 za aplikacije Ku and K-pojasa

Izvorni znanstveni članak U ovom je radu prikazana mikrostrip antena na podlozi Duroid 5870 za aplikacije Ku i K pojasa. Predložena se antena sastoji od kružnih i pravokutnih nizova tiskanih na dielektričnom materijalu podloge Duroid 5870, a pobuđuje ju $50 \Omega$ mikrostrip dalekovod. HFSS elektromagnetski solver visoke frekvencije uzet u obzir u ovoj studiji temelji se na metodi konačnih elemenata (MKE). Antena generira dvije odvojene rezonantne frekvencije za pokrivanje Ku i K-pojasa. Ima područje impedancije $(2: 1 \mathrm{VSWR})$ od $1,11 \mathrm{GHz}(16,14 \div 15,03 \mathrm{GHz})$ na donjem pojasu i širinu pojasa od $1,15 \mathrm{GHz}(20,99$ $\div 19,84 \mathrm{GHz})$ na gornjem pojasu. Postigla je stabilan kružni dijagram zraćenja u operativnom frekvencijskom pojasu. Predstavljeni su i detaljno raspravljeni učinkovitost, raspodjela struje, VSWR te povratni gubitci predložene antene.

Ključne riječi: Duroid 5870; K-pojas; Ku-pojas; mikrostrip (mikrotrakasta) antena; mikrostrip (mikrotrakasta) linija

\section{Introduction}

Microstrip antenna is a harbinger in wireless communication systems and is executing to face the changing demands of update antenna technology. Microstrip patch antennas are extensively used in wireless communication system, since they are conformal, have a low profile, easier to fabricate with Integrated Circuit (IC), easy integration with array and electronic components. Advances in wireless communications have introduced tremendous demands in the antenna technology. It also paved the way for wide usage of mobile phones in modern society resulting in mounting concerns surrounding its harmful radiation $[1 \div 6]$. The substrate material Duroid 5870 is suitable for higher frequency owing to the lowest electrical loss and can be used in circuitry for commercial airline telephones, millimeter wave applications and digital radio antennas. Many researchers have heavy interest to design $\mathrm{Ku}$ and K-band antennas and still face a major challenge to implement these applications. Patch is the dominant figure of a microstrip antenna and substrate and ground are the other components which are two sides of patch [1]. Many dual-band antennas have been improved to face the rising demands for a modern portable wireless communication device which is capable of integrating more than one communication standard into a single system. For this reason, different types of antenna designs have been narrated $[7 \div 11]$.

In ref. [12], a multi band patch antenna has been designed for $\mathrm{Ku}$ and $\mathrm{K}$-band applications where dimension is $8 \times 10 \mathrm{~mm}$, bandwidth is $760 \mathrm{MHz}$, peak gain is $4,5 \mathrm{~dB}$. In ref. [13], a dual polarized microstrip patch antenna has been proposed for $\mathrm{Ku}$-band applications where dimension is $15 \times 15 \mathrm{~mm}$ and $\mathrm{MHz}$
$950 \mathrm{MHz}$ bandwidth has been achieved with maximum gain 7,6 dB. In ref. [14], a Ku-band patch antenna has been proposed with notches and slit where dimension is $7,6 \times 10 \mathrm{~mm}$, substrate thickness is $0,8 \mathrm{~mm}$; Teflon is used as dielectric substrate material and maximum 600 $\mathrm{MHz}$ bandwidth has been obtained. In ref. [15], a dual band compact microstrip antenna has been proposed for Ku-band applications using three pairs of thin slits from the sides of a rectangular patch where dimension is $9,5 \times$ $10 \mathrm{~mm}$, substrate thickness is $0,254 \mathrm{~mm}$, Rogers RT/Duroid 5880 is used as dielectric substrate material and maximum $90 \mathrm{MHz}$ bandwidth has been obtained. In ref. [16], a dual frequency triangular slotted microstrip patch antenna has been proposed for Ku-band applications where patch dimension is $8,5 \times 7,96 \times 1,905$ $\mathrm{mm}$. substrate thickness is $1,905 \mathrm{~mm}$, Rogers RT/Duroid 6010 is used as dielectric substrate material and maximum $576 \mathrm{MHz}$ bandwidth has been achieved. In all these above proposed antenna designs, narrow bandwidth has been achieved for Ku-band applications.

In ref. [17], a compact dual band microstrip antenna for $\mathrm{Ku}$-band applications has been proposed where dimension is $9,50 \times 10 \times 0,254 \mathrm{~mm}$, achieved return loss is $-23,83 \mathrm{~dB}$ at $12,54 \mathrm{GHz}$ and $-14,04$ at $14,15 \mathrm{GHz}$ respectively, and gain is greater than $4 \mathrm{dBi}$. Comparatively, the proposed antenna has limited return loss. A printed double-T monopole antenna has been proposed in ref. [18]. A surface mount dual loop antenna has been proposed in ref. [19]. A dual band reduced size PIFA has been proposed in ref. [20]. These antennas provided dual-band features to cover the 2,4/5,2 and 5,8 $\mathrm{GHz}$ WLAN bands. The limitations of these antennas were that they could not deliver uniform omni-directional radiation pattern. A low cost microstrip fed dual frequency printed dipole antenna has been proposed for 
wireless communications in ref. [21]. This antenna size is large and bandwidth is limited. In [22], a printed dual band dipole antenna with U-slot arms has been proposed for $2,4 / 5,2 \mathrm{GHz}$ WLAN operation. The bandwidth is insufficient to cover the desired band that is $370 \mathrm{MHz}$.

In ref. [23], a dual broad band design of rectangular slot antenna has been proposed for 2,4 and $5 \mathrm{GHz}$ wireless. The antenna dimension is $75 \times 75 \mathrm{~mm}$, substrate permittivity is 4,70 and thickness is $0,80 \mathrm{~mm}$. In ref. [24], a dual-band WLAN dipole antenna has been proposed using an internal matching circuit. The antenna dimension is $12 \times 45 \mathrm{~mm}$ and FR4 is used as dielectric substrate material to cover the desired bands.

In this study, a $20 \times 20 \mathrm{~mm}$ microstrip patch antenna has been designed on $1,575 \mathrm{~mm}$ thick Duroid 5870 substrate material for $\mathrm{Ku}$ and K-band applications. Downlink frequency $15,56 \mathrm{GHz}$, uplink frequency 20,41 $\mathrm{GHz}$, return loss $-32,56 \mathrm{~dB}$ and $-31,13 \mathrm{~dB}$, peak gain $3,90 \mathrm{~dB}$ and $98,5 \%$ average efficiency have been achieved. The detailed design and simulation results for the proposed antenna are demonstrated later.

\section{Antenna design and optimization}

The design of the proposed antenna has been shown in Fig. 1. The antenna has been comprised of six conducting slots on patch and two on the ground. A circular slot and five rectangular slots are on the patch and two rectangular slots on the ground of proposed the antenna. The design procedure begins with the radiating patch with substrate, ground plane and a feed line. It is printed on a $1,575 \mathrm{~mm}$ thick Duroid 5870 substrate material that contains relative permittivity 2,33 , relative permeability 1 , and dielectric loss tangent 0,0012. A circular and five rectangular slots are cut from the rectangular copper patch. The other two rectangular slots are also cut from the ground plane. Thus, the proposed slotted circle patch antenna is achieved finally.

Here, microstrip line is used to provide feeding to the proposed antenna. The Sub Miniature version A (SMA) connector that contains $50 \Omega$ is conducted at the end of antenna feeding line for input RF signal.

The antenna design and dimensions were investigated by using the Ansoft HFSS software, that is built on the Finite Element Method (FEM), and finally the optimal dimensions were determined as follows: $L=20 \mathrm{~mm}, L_{\mathrm{g}}=$ $20 \mathrm{~mm}, L_{1}=8 \mathrm{~mm}, L_{2}=3 \mathrm{~mm}, L_{3}=16 \mathrm{~mm}, R=2 \mathrm{~mm}, W$ $=20 \mathrm{~mm}, W_{\mathrm{g}}=20 \mathrm{~mm}, W_{1}=4 \mathrm{~mm}, W_{2}=3 \mathrm{~mm}$ and $W_{3}=$ $3 \mathrm{~mm}$.

There are different types of material for antenna substrate. Duroid 5870 is high frequency laminate and PTFE (Polytetrafluoroethylene) composite amplified using glass microfibers. Finally, in order to increase the advantages of the fiber reinforcement towards circuit applications and circuit producers, these microfibers are used aimlessly. The dielectric constant of Duroid 5870 substrate material is lower than other products and is suitable for higher frequency bands where dispersion and losses require to be decreased because of low dielectric loss. Owing to extensive low water excitement features, Duroid 5870 substrate is standard for utilizations in heavy moisture environments. It is detruncated simply, machined and sheared to shape as well as obstacle to all reagents and solvents usually used in engraving printed circuit boards or plating holes and edges. It has the lowest electrical loss of any amplified PTFE substrate material, absorption of lower moisture is isotropic, and has identical electrical characteristics over frequency.

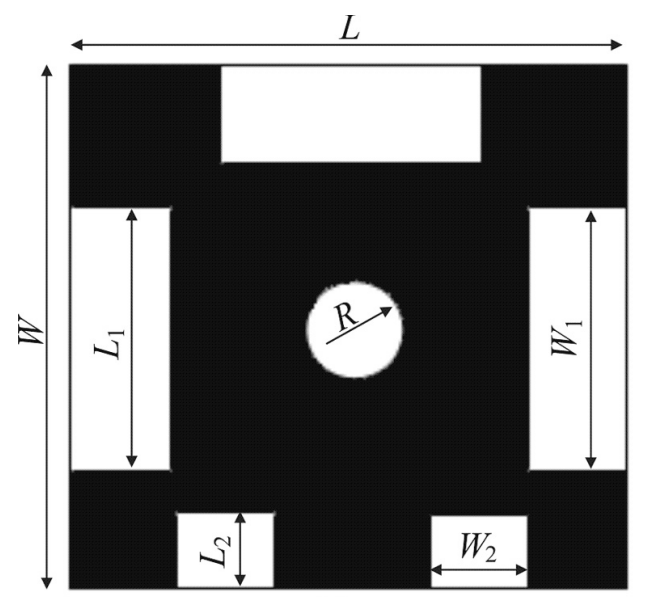

(a)

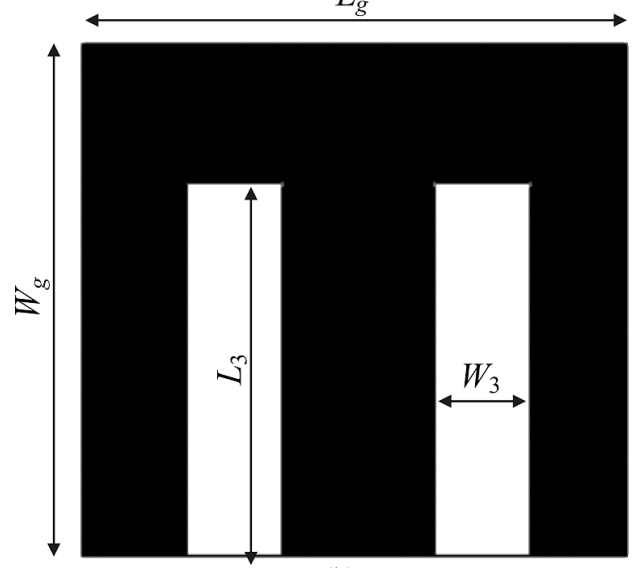

(b)

Figure 1 Proposed antenna a) Top view b) Bottom view

Table 1 Dielectric properties of substrate materials

\begin{tabular}{|l|c|c|}
\hline \multicolumn{1}{|c|}{ Material } & Permittivity & Loss tangent \\
\hline Duroid 6010 & 10,20 & 0,0023 \\
\hline $\mathrm{AL}_{2} \mathrm{O}_{3}$ & 9,80 & 0,0009 \\
\hline $\mathrm{FR} 4$ & 4,66 & 0,0200 \\
\hline Duroid 5870 & 2,33 & 0,0023 \\
\hline
\end{tabular}

It has been used in circuitry for commercial airline telephones, stripline and microstrip circuits, military radar systems, millimetre wave applications, point-to-point digital radio antennas as well as missile guidance systems.

For these reasons, Duroid 5870 substrate material has been finally chosen for the proposed antenna design to reach the desired bands. The dielectric properties of substrate materials have been listed in Tab. 1. The equivalent of the proposed antenna is represented as a parallel combination of resistor $\mathrm{R}$, inductor $\mathrm{L}$ and capacitor $\mathrm{C}$ as shown in Fig. 2.

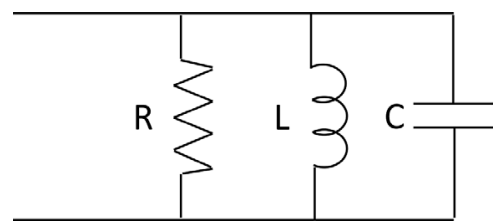

Figure 2 Equivalent circuit of the proposed antenna 
The length, width, VSWR, return loss of the patch antenna can be calculated from the equations (1) - (6) narrated in ref. [25]. Where $\mathrm{L}$ and $\mathrm{W}$ are the length and width of the patch, $\mathrm{c}$ is the velocity of light, $\varepsilon_{r}$ is the dielectric constant of substrate, $\mathrm{h}$ is the thickness of the substrate, $f_{0}$ is the target center frequency, $\varepsilon_{e}$ is the effective dielectric constant and $\rho$ is the radiation coefficient.

$$
\begin{aligned}
& W=\frac{c}{2 f_{0}}=\sqrt{\frac{\varepsilon_{r}+1}{2}}, \\
& L=\frac{c}{2 f_{0} \cdot \sqrt{\varepsilon_{r}}}-2 \Delta l, \\
& \varepsilon_{e}=\frac{1}{2}\left(\varepsilon_{r}+1\right)+\frac{1}{2}\left(\varepsilon_{r}-1\right) \sqrt{\left(1+\frac{10 h}{W}\right),} \\
& \Delta l=0,412 h \frac{\left(\varepsilon_{e}+0,3\right)\left[\frac{W}{h}+0,8\right]}{\left(\varepsilon_{e}-0,258\right)\left[\frac{W}{h}+0,8\right]} .
\end{aligned}
$$

$V S W R=\frac{1+\rho}{1-\rho}$,

Return loss $=-10 \log \left(\frac{1}{\rho^{2}}\right)$.

\section{Results and discussions}

The entire simulation has been done to perform the resonant requirements of the proposed antenna design using Finite Element Method (FEM) based high frequency simulation software HFSS. The simulated return loss with different substrate materials is shown in Fig. 3.

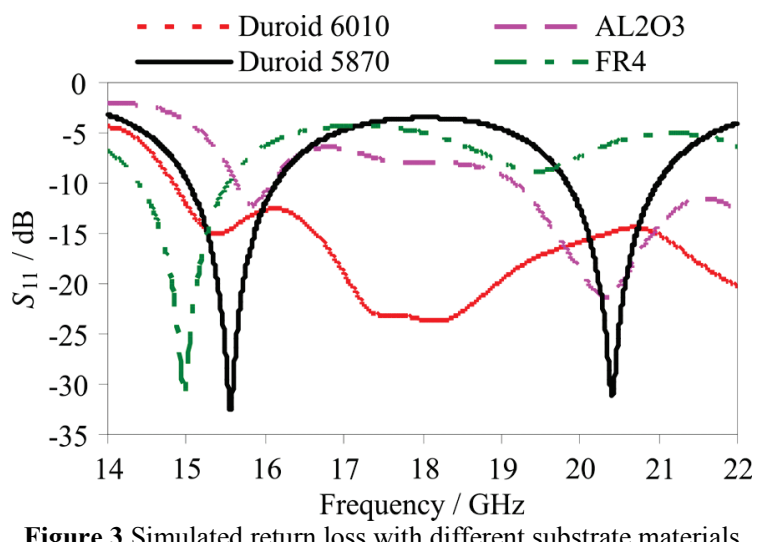

Figure 3 Simulated return loss with different substrate materials

When high permittivity material Duroid 6010 is used as substrate, resonance is achieved but that is not desired. Two resonances have been obtained using $\mathrm{AL}_{2} \mathrm{O}_{3}$ ceramic as substrate material. But return loss of these two resonances is very low, which is unwanted. When FR4 has been used, one resonance has been found that is not needed for dual band operation. Finally, Duroid 5870 is used in the proposed design and two strong resonances have been achieved with wide bandwidth and gain.

A parametric study has been done to observe the effects of the proposed antenna parameters. Mainly, the effects of the different parameters on the return loss have been observed. In these simulations, the other parameters are unchanged without the desired parameter.

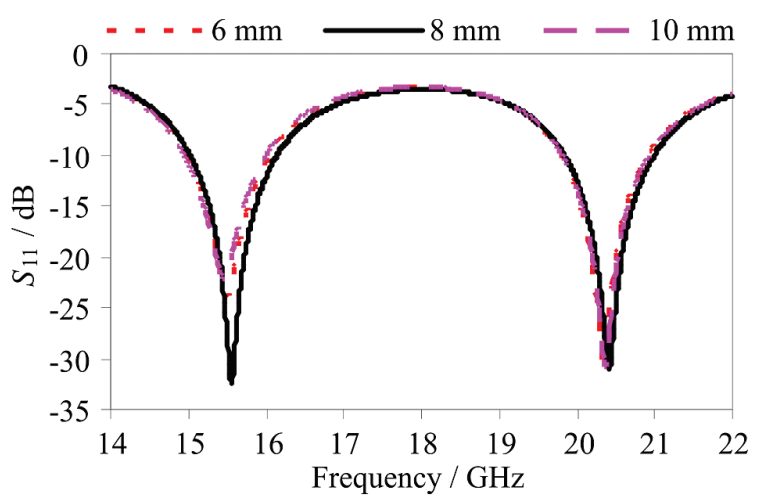

Figure 4 Simulated return loss for different values of $L_{1}$

Fig. 4 shows the simulated return loss for different values of $L_{1}$. Two resonances have been observed using the above values of $L_{1}$, one for lower band and the other for upper band. Return loss of lower band is low using $L_{1}$ $=6 \mathrm{~mm}$ and $L_{1}=10 \mathrm{~mm}$. $L_{1}=8 \mathrm{~mm}$ can be taken as optimized value to achieve both lower and upper bands.

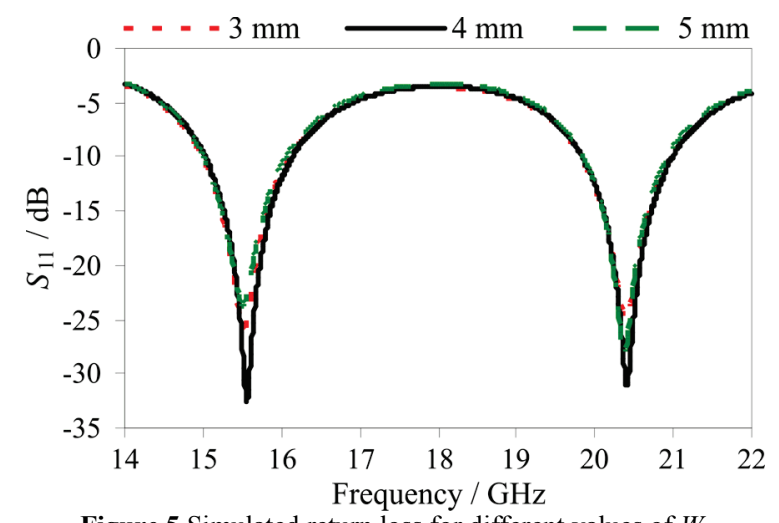

Figure 5 Simulated return loss for different values of $W_{1}$

Fig. 5 shows the simulated return loss for different values of $W_{1}$. Two resonances have been found using the above values of $W_{1}$. Return loss is lower with using $W_{1}=$ $3 \mathrm{~mm}$ and $W_{1}=5 \mathrm{~mm}$ than with $W_{1}=4 \mathrm{~mm}$. $W_{1}=4 \mathrm{~mm}$ is the optimized value.

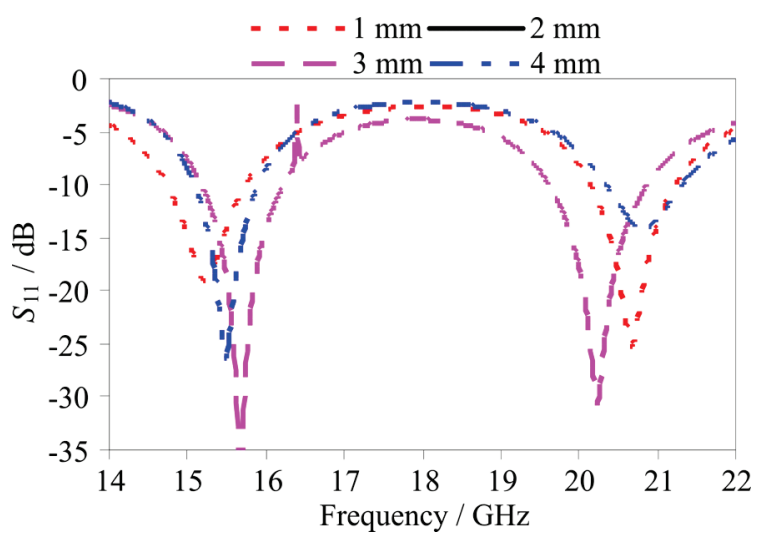

Figure 6 Simulated return loss for different values of $R$

Fig. 6 shows the simulated return loss for different values of $R$. The radius of the circular slot, $R$ is an important parameter that plays a role to determine the desired frequency bands. Resonances are shifted using the 
value of radius as $1 \mathrm{~mm}, 3 \mathrm{~mm}$ and $4 \mathrm{~mm}$. By using $R=2$ $\mathrm{mm}$, desired dual band has been obtained with improved bandwidth.

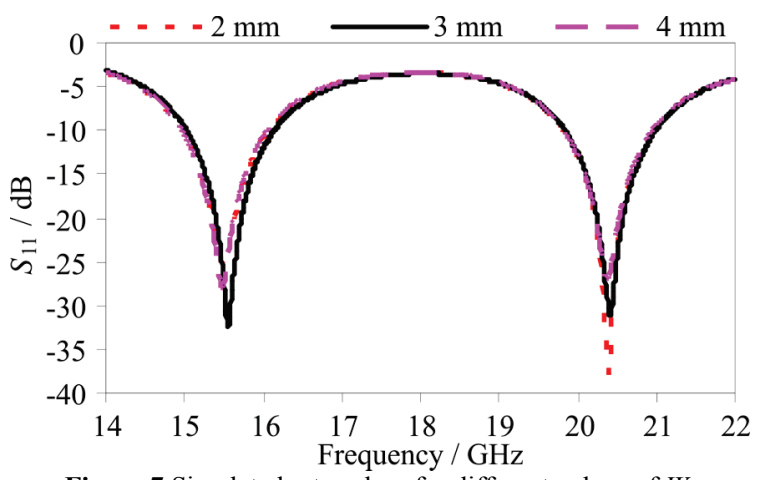

Figure 7 Simulated return loss for different values of $W_{2}$

Fig. 7 shows the simulated return loss for different values of $W_{2}$. By using $2 \mathrm{~mm}$ return loss is low on the lower band but high on the upper band. Return loss is low both on the upper and the lower band with using $4 \mathrm{~mm}$. The optimized value is $3 \mathrm{~mm}$ that is appropriate on both bands.

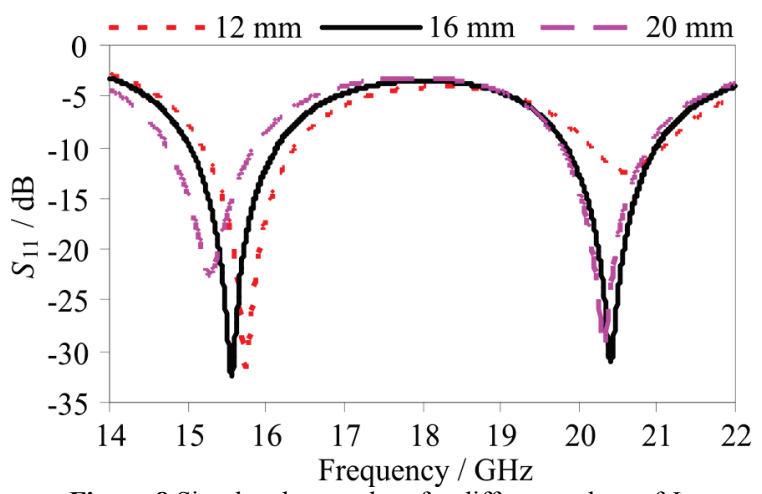

Figure 8 Simulated return loss for different values of $L_{3}$

Fig. 8 shows the simulated return loss for different values $L_{3}$. By using $12 \mathrm{~mm}$, return loss is high on the lower band but low on the upper band. By using $20 \mathrm{~mm}$, return loss is low on the lower band but high on the upper band. The optimized value is $16 \mathrm{~mm}$. The simulated return loss for different values $W_{3}$ is shown in Fig. 9. It can be easily realized that the optimized value is $3 \mathrm{~mm}$ that is better than the other two values, $2 \mathrm{~mm}$ and $4 \mathrm{~mm}$.

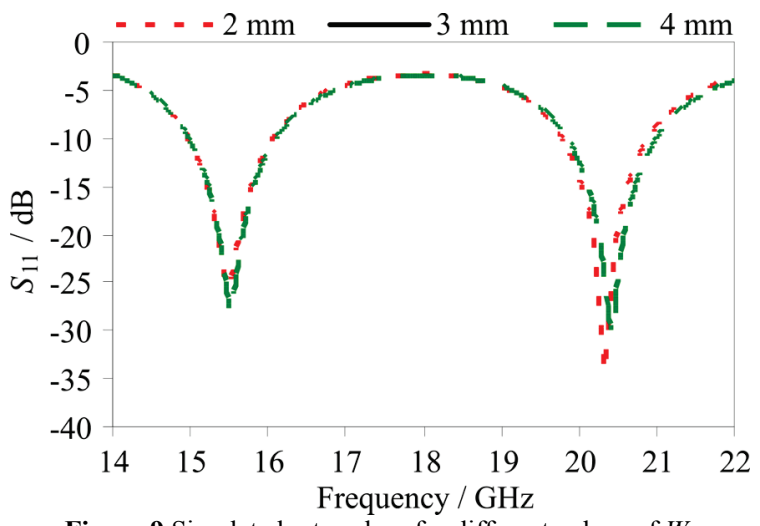

Figure 9 Simulated return loss for different values of $W_{3}$

The simulated return loss of the proposed antenna is shown in Fig. 10. Return loss of $-32,56 \mathrm{~dB}$ has been obtained on the lower band frequency $15,56 \mathrm{GHz}$ and $31,13 \mathrm{~dB}$ on the upper band frequency $20,41 \mathrm{GHz}$. In ref. [26], a wideband E-shaped patch antenna has been proposed for wireless applications where dimension is 76 $\times 45 \mathrm{~mm}$ and bandwidth is $230 \mathrm{MHz}$. A dual band annular slot antenna has been proposed for GPS receiver in ref. [27] where dimension is $100 \times 100 \mathrm{~mm}$ and bandwidth is $45 \mathrm{MHz}$ on the lower band and $20 \mathrm{MHz}$ on the upper band. On the contrary, we have achieved for the $1^{\text {st }}$ resonance at $1,11 \mathrm{GHz}(16,14 \mathrm{GHz} \div 15,03 \mathrm{GHz})$ bandwidth and for the 2 nd resonce at $1,15 \mathrm{GHz}(20,99$ $\mathrm{GHz} \div 19,84 \mathrm{GHz}$ ) respectively.

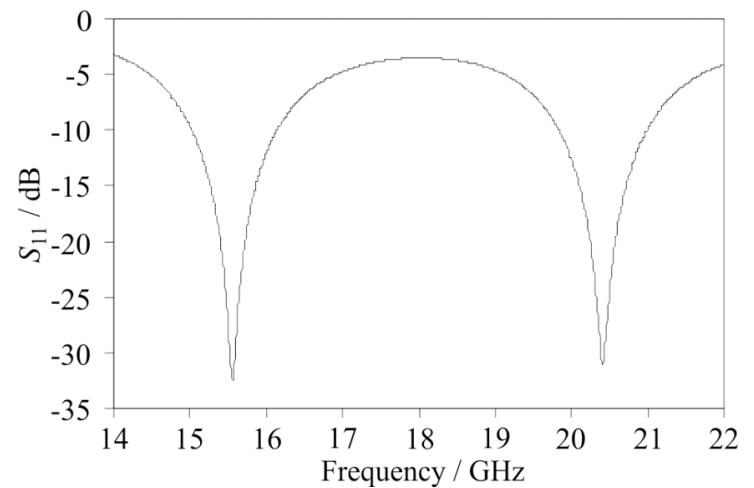

Figure 10 Return loss of the proposed antenna

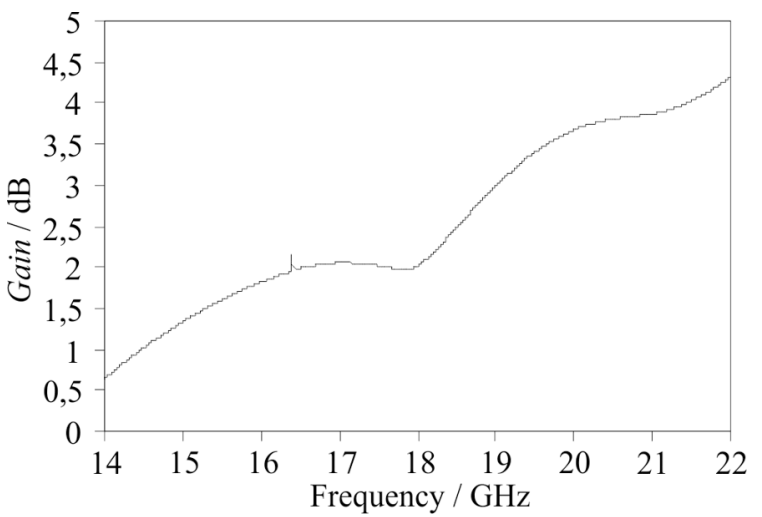

Figure 11 Gain of the proposed antenna

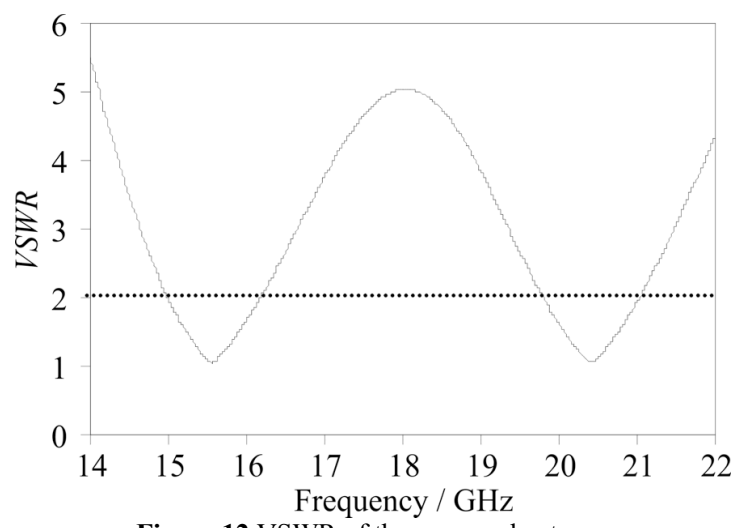

Figure 12 VSWR of the proposed antenna

The simulated gain of the proposed antenna is exhibited in Fig. 11. The achieved gains are $1,87 \mathrm{~dB}$ on the lower band and $3,87 \mathrm{~dB}$ on the upper band respectively. The simulated VSWR of the proposed antenna is indicated in Fig. 12. The standard value of VSWR is less than 2 for the operational bands of the microstrip patch antenna. 


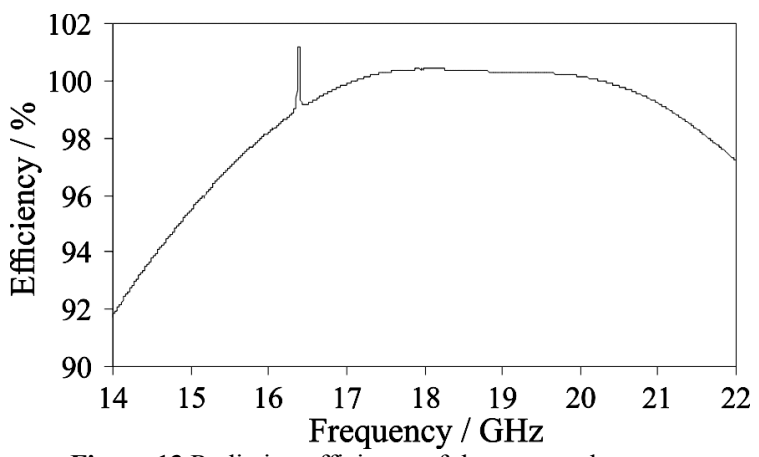

Figure 13 Radiation efficiency of the proposed antenna

It can be observed apparently that less than 2 value of VSWR has been achieved in the desired operating bands.

The radiation efficiency of the proposed antenna is displayed in Fig. 13. It can be observed that 98,5\% efficiency has been acquired on the entire operating band of $\mathrm{Ku}$ and $\mathrm{K}$-band applications.

The radiation pattern of the proposed antenna is illustrated in Fig. 14 for a) E-plane at $15,56 \mathrm{GHz}$, b) $\mathrm{H}$ plane at 5,56 GHz, c) E-plane at $20,41 \mathrm{GHz}$ and d) $\mathrm{H}$ plane at $20,41 \mathrm{GHz}$. The $E_{\varphi}$ and $E_{\theta}$ fields indicate the cross-polar and co-polar components respectively. It is wanted in case of standard radiation pattern of a microstrip antenna that the effect of cross-polarization is lower than that of co-polarization. The cross polarization effect is higher in the $2^{\text {nd }}$ resonant frequency $20,41 \mathrm{GHz}$. When frequency increases, the effect increases interpreting from the radiation pattern simply. Moreover, almost omni-directional and symmetrical radiation patterns have been attained along both E-plane and $\mathrm{H}$ plane. It has been observed that the same radiation pattern exists over the $\mathrm{Ku}$ and $\mathrm{K}$-bands. The obtained radiation patterns indicate that the proposed antenna delivers linear polarization where the level of cross-polarization is lower than that of co-polarization in all of the simulated radiation patterns. When the radiation pattern of a microstrip antenna is symmetric and omni-directional, it faces some reasonable benefits. One is that resonance would never be shifted at different directions and a large amount of stable power would be at the direction of broadside beam. Another advantage is that the radiation pattern would be more durable on the operational bands.

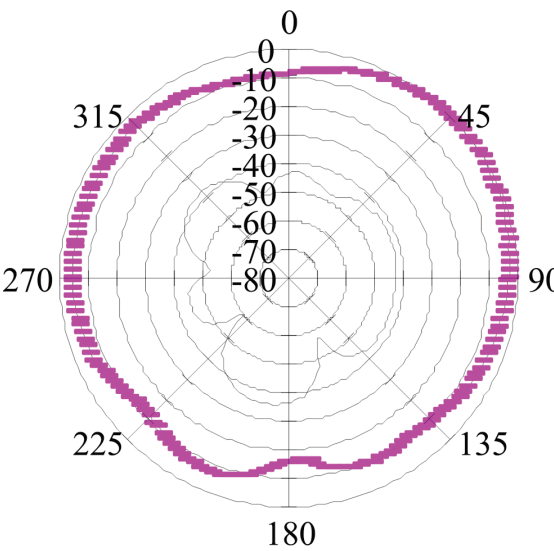

(a)

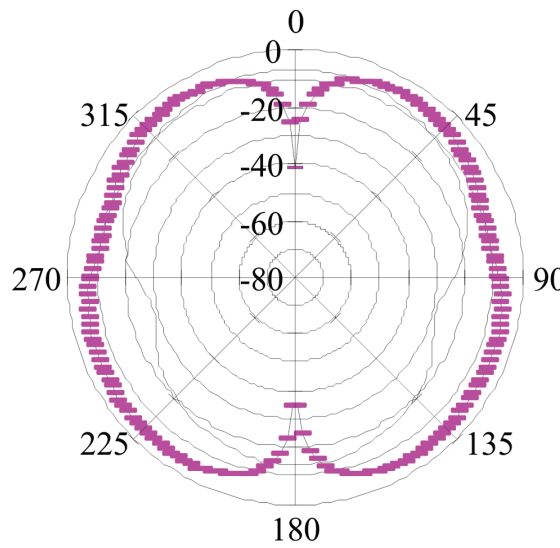

(c)

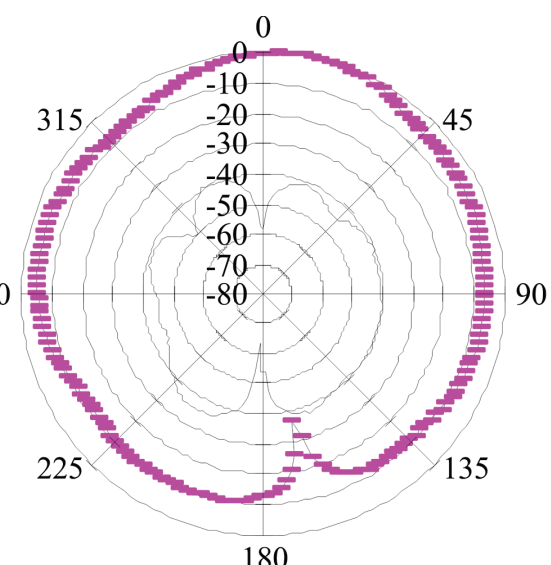

(b)

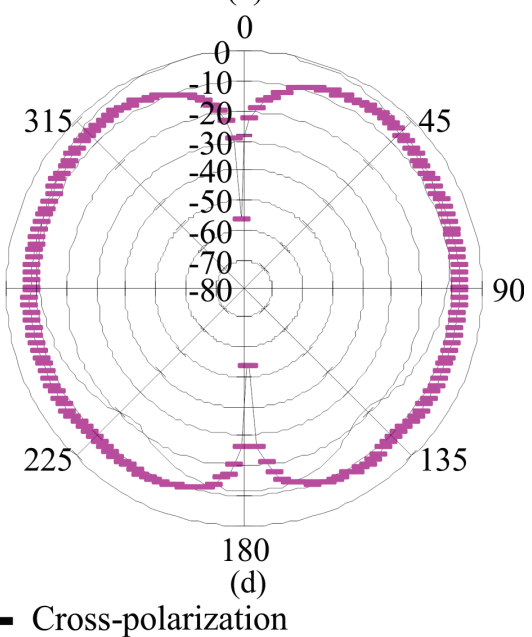

Figure 14 Radiation pattern of the proposed antenna: a) E-plane at 15,56 GHz, b) H-plane at 15,56 GHz, c) E-plane at 20,41 GHz, d) H-plane 20,41 GHz

The level of cross-polarization at higher frequencies is comparatively richer than lower frequencies that are desired to be owing to the diffractions from the edges of the patch and ground plane. As the level of this cross polarization is observed to be reduced by enhancing the slots on the ground plane. In this point, the radius of the circular slot on the patch is also responsible for this effect.
In this way, this enhancement of the slots will be found later. The values of the other parameters are fixed. The results indicate that the radiation patterns are lightly shifted at the higher frequency, as the distribution of the non-uniform phase is created on the proposed antenna. In this way, these radiation patterns are suitable for $\mathrm{Ku}$ and K-band. The dimensions of the patch and the ground 
plane identify the radiation pattern degradation over the entire $\mathrm{Ku}$ and $\mathrm{K}$-bands. For that reason, the size of patch and ground plane has been selected carefully.
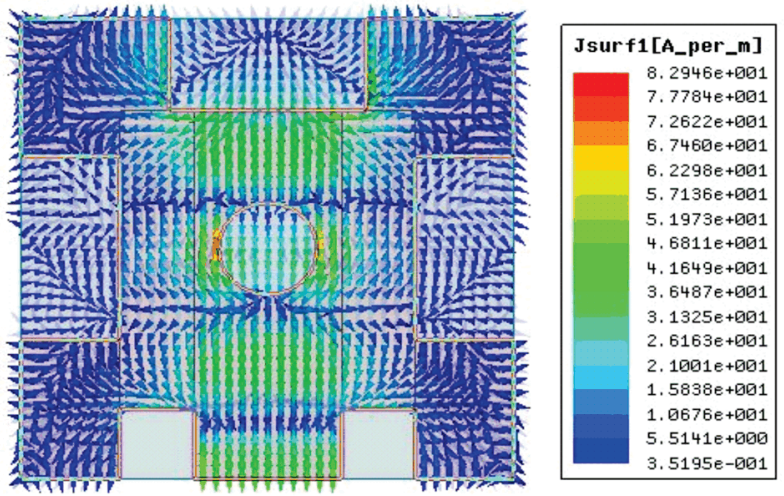

(a)
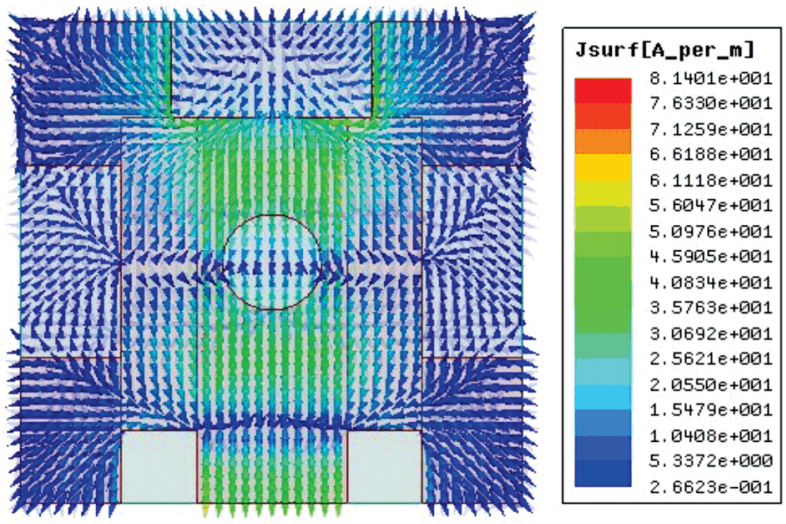

(b)

Figure 15 Current distribution of the proposed antenna at a) $15,56 \mathrm{GHz}$ and b) $20,41 \mathrm{GHz}$

If any parameter is changed, resonant frequency is shifted. As a result radiation pattern is also changed from symmetric and omni-directional to bidirectional or other type.

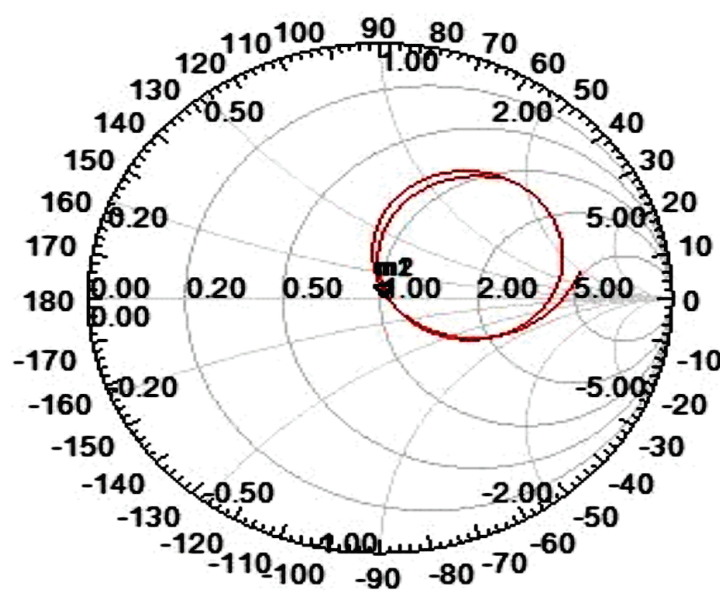

\begin{tabular}{|c|c|c|c|c|}
\hline Name & Freq & Ang & Mag & RX \\
\hline$m 1$ & 15.5600 & 31.0377 & 0.0235 & $1.0409+0.0253 \mathrm{i}$ \\
\hline $\mathrm{m} 2$ & 20.4100 & 24.1932 & 0.0277 & $1.0516+0.0239 \mathrm{i}$ \\
\hline
\end{tabular}

Figure 16 The smith chart of the proposed antenna

Fig. 15 has plotted the current distribution of the proposed antenna for a) $15,56 \mathrm{GHz}$ and b) $20,41 \mathrm{GHz}$. It can be observed that current distribution is equal on both the upper and lower band radiating elements in the 15,56 $\mathrm{GHz}$. Flow of current is distributed symmetrically on both the patch and the ground radiators at the higher frequency of $20,41 \mathrm{GHz}$. As a result, it can be realized that a large amount of current flows at feeding line. Electric field has been created much in this point.

The creation of electric field near slots is reasonable. As a result, excitation is strong in the entire parts of the antenna on both the lower band and the upper band.

The smith chart of the proposed antenna is plotted in Fig. 16. When dimensions of the patch and the ground plane are changed, the coupling and the input impedance shift at different resonant loops. It can be observed that the tightest resonant loop is at the center of the smith chart of the proposed antenna design. This indicates the improved bandwidth of the proposed antenna.

\section{Conclusion}

A microstrip antenna on Duroid 5870 substrate material to cover $\mathrm{Ku}$ and $\mathrm{K}$-band applications has been demonstrated. The $10 \mathrm{~dB}$ bandwidth $1,11 \mathrm{GHz}$ in the $1^{\text {st }}$ resonance $15,56 \mathrm{GHz}$ and $1,15 \mathrm{GHz}$ in the $2^{\text {nd }}$ resonance $20,41 \mathrm{GHz}$ have been complied with all the conditions of any $\mathrm{Ku}$ and $\mathrm{K}$ - band applications.

Attractive radiation patterns, low cross polarization, efficiency with improved bandwidth and higher gain make the proposed antenna compatible for using $\mathrm{Ku}$ and K-band applications.

\section{References}

[1] Weng, L. H.; Guo, Y. C.; Shi, X. W.; Chen, X. Q. An overview on defected ground structure. // Progress in Electromagnetic Research B. 7, (2008), pp.173-189.

[2] Islam, M. T.; Faruque, M. R. I.; Misran, N. SAR reduction in a muscle cube with metamaterial attachment. // Applied Physics A: Materials Science and Processing. 103, 2 (2011), pp. 367-372.

[3] Faruque, M. R. I.; Islam, M. T.; Misran, N. Design analysis of new metamaterial for EM absorption reduction. // Progress in Electromagnetics Research. 124, (2012), pp. 119-135.

[4] Husni, N. A.; Faruque, M. R. I.; Islam, M. T.; Misran, N. Effects of electromagnetic absorption towards human head due to variation of its dielectric properties at 900, 1800 and $1900 \mathrm{MHz}$ with different antenna substrates. // Progress in Electromagnetics Research. 138, (2013), pp. 367-388.

[5] Islam, M. T.; Abidin, H. Z.; Faruque, M. R. I.; Misran, N. Analysis of materials effects on radio frequency electromagnetic fields in human head. // Progress in Electromagnetics Research. 128, (2012), pp. 121-138.

[6] Faruque, M. R. I.; Islam, M. T.; Misran, N. Electromagnetic (EM) absorption reduction in a muscle cube with metamaterial attachment. // Medical Engineering \& Physics. 33, 5 (2011), pp. 646-652.

[7] Liu, W. -C.; Hsu, C. -F. Dual-band CPW-fed Y-shaped monopole antenna for PCS/WLAN application. // Electron. Lett. 41, 7(2005), pp.390-391.

[8] Wu, C. -M. Dual-band CPW-fed cross-slot monopole antenna for WLAN operation. // IET Microwave Antennas \& Propag. 1, 2(2007), pp. 542-546.

[9] Augustin, G.; Shynu, S. V., Mohanan, P., Aanandan, C. K., Vasudevan, K. Compact dual-band Antenna for wireless access point. // Electron. Lett. 42, 9(2006), pp. 502-503. 
[10] Hsieh, C. P.; Chiu, T.C.; Lai, C. H. Compact dual-band slot antenna at the corner of the ground plane. // IEEE Trans. Antennas Propag. 57, 10(2009), pp. 3423-3426.

[11] Liu, W. -C.; Wu, C. -M.; Chu, N. -C. A compact CPW-fed slotted patch antenna for dual-band operation. // IEEE Antenna Wirel. Propag. Lett. 9, (2010), pp. 110-113.

[12] Ullah, M. H.; Islam, M. T.; Mandeep, J. S.; Misran, N. Design and analysis of a multi band electrically small antenna using ceramic material substrate. // Przeglad Elektrotechniczny. (2013), pp 271-274.

[13] Azim, R.; Islam M. T.; Misran, N. Dual polarized microstrip patch antenna for Ku-band application. // Informacije MIDEM. 41, 2(2011), pp. 114-117.

[14] Dubey, S. K.; Pathak, S. K.; Modh, K. K. High Gain Multiple Resonance Ku-band Microstrip Patch Antenna. // Proceedings of IEEE. (2011), pp. 1-3.

[15] Misran, N.; Islam, M. T.; Yusob ,N. M.; Mobashsher A. T., Design of a Compact Dual Band Microstrip Antenna for $\mathrm{Ku}$-Band Application. // Proceedings of IEEE. (2009), pp. 699-702.

[16] Samsuzzaman, M.; Islam, M. T.; Yatim, B.; Ali, M. A. M. Dual Frequency Triangular Slotted Microstrip Patch Antenna for $\mathrm{Ku}$ Band Applications. // Przeglad Elektrotechniczny. (2013), pp. 275-279.

[17] Islam, M. T.; Misran, N.; Mobashsher, A. T. Compact Dual Band Microstrip Antenna for Ku-Band Application. // Information Technology Journal. 9, 2(2010), pp. 354-358.

[18] Kuo, Y.-L.; Wong, K.-L. Printed double-T monopole antenna for $2.4 / 5.2 \mathrm{GHz}$ dual band WLAN operations. // IEEE Trans. Antennas Propag. 51, 9(2003), pp. 2187-2192.

[19] Lin, C. C.; Lee, G. Y.; Wong, K. L. Surface mount dual loop antenna for $2.4 / 5 \mathrm{GHz}$ WLAN operations. // Electr. Lett., 39, 18(2003), pp. 1302-1304.

[20] Nashaat, D.; Elsadek, H. A.; Ghali, H. Dual band reduced size PIFA antenna with U-slot for blue tooth and WLAN operations. // Proc. IEEE Antennas and Propagation Society International symposium / USA, 2003, pp. 962-965.

[21] Suh, Y. H.; Chang, K. Low cost microstrip fed dual frequency printed dipole antenna for wireless communications. // Electr. Lett. 36, 14(2000), pp. 11771179 .

[22] Su, C. M.; Chen, H. T.; Wong, K. L. Printed dual band dipole antenna with U-slot arms for 2.4/5.2 GHz WLAN operation. // Electr. Lett. 38, 22(2002), pp. 1308-1309.

[23] Wu, J. W.; Hsiao, H. M.; Lu, J. H.; Chang, S. H. Dual broad band design of rectangular slot antenna for 2.4 and 5 $\mathrm{GHz}$ wireless. // IEEE Electron. Lett. 40, 23(2004), pp. 1461-1463.

[24] Zhang, Z.; Iskander, M. F.; Langer, J. C.; Mathews, J. Dual-band WLAN dipole antenna using an internal matching circuit. // IEEE Trans. Antennas Propag. 53, 5(2005), pp. 1813-1818.

[25] Bahl, I. J.; Bhartia, P. Microstrip Antennas, 2nd Edn. Artech House, Boston, London, 1980.

[26] Khidre, A.; Lee, K.; Yang, F. F.; Eisherbeni, A. Wideband circularly polarized E-shaped patch antenna for wireless applications. // IEEE Antennas and Propag. Magazine. 52, 5(2010), pp. 219-229.

[27] Hsieh, T.; Chang, T. H.; Kiang, J. F. Dual-Band circularly polarized cavity-backed annular slot antenna for GPS receiver. // IEEE Trans. Antennas Propag. 60, 4(2012), pp. 2076-2080.

\section{Authors' addresses}

Md. Moinul Islam, B.Sc., M.Sc.

Institute of Space Science (ANGKASA)

Universiti Kebangsaan Malaysia

43600 UKM, Bangi, Selangor D. E., Malaysia

E-mail:mmoiislam@yahoo.com

Mohammad Tariqul Islam, Professor

Institute of Space Science (ANGKASA)

Universiti Kebangsaan Malaysia

43600 UKM, Bangi, Selangor D. E., Malaysia

Mohammad Rashed Iqbal Faruque, Assistant Professor Institute of Space Science (ANGKASA)

Universiti Kebangsaan Malaysia

43600 UKM, Bangi, Selangor D. E., Malaysia 